\title{
Changes in henna (Lawsonia inermis L.) morphological traits under different deficit irrigations in the southern Tunisia
}

\author{
Hanen Enneb ${ }^{1}$, Aicha Belkadhi ${ }^{2 \otimes}$, and Ali Ferchichi ${ }^{1}$
}

\begin{abstract}
Henna plant belongs to continental oases where water shortage constitutes the essential limiting factors of its agricultural production. Lawsonia inermis L. (Lytraceae) is often exposed to severe drought stress in Gabes; a Tunisian arid region. The present study was carried out to evaluate the impact of water stress on the morphology of Tunisian henna plants. Thus, an experiment of four months was carried out under greenhouse at the Institute of Arid Region in Medenine, Tunisia. Henna was exposed to three different irrigation regimes, whereby the plants where irrigated to field capacity (control, T0), $50 \%$ of the control (moderate stress, T1) and $25 \%$ of the control (severe deficit irrigation, T2). Results showed that, leaf area (LA), leaf number and stem length of henna, decreased in response to the studied stress. The effect of water stress was clearly observed on those parameters. Moderate drought (T1) did not damage henna morphology, and the plants grew better than without water limitation (T0). Furthermore, the water stress-typical responses were shown as time and severity dependent in all the measured parameters. Indeed, lowest water availability treatment (T2) induced significant decrease in total number of leaves, as well as
\end{abstract}

Received: 4 November 2014

Accepted revised version: 16 December 2014

Published online: 1 January 2015

(C) Enneb et al (2015)

Publisher: Horizon e-Publishing Group

\section{CITATION}

Enneb, H., A. Belkadhi, and A. Ferchichi1. 2015. Changes in henna (Lawsonia inermis L.) morphological traits under different deficit irrigations in the southern of Tunisia. Plant Science Today 2: 2-6. doi: 10.14719/pst.2015.2.1.92

\section{AUTHOR'S AFFILIATION}

1 Laboratory of Dryland and Oasis Cropping, Institute of Arid Zone of Medenine, ElFjè, Medenine 4119, Tunisia

2 Department of Biology, Unité de Recherche de Physiologie et Biochimie de la tolérance des plantes aux contraintes abiotiques, Faculty of Sciences of Tunis, University of Tunis El Manar, 1060 Tunis, Tunisia.

CORRESPONDENCE

$\triangle$ Dr. Aicha Belkadhi Email: aicha585@yahoo.ca reductions in LA. Under this severe water stress (T2); LA was reduced by $65.79 \%$, compared to control, at 60 days after the initiation of the bioassay. Stem length decreased significantly in the most severe water stress, this reduction was about $44 \%$. Globally, we conclude that henna plant growth decreased progressively to long-term water limitation.

Keywords: Lawsonia inermis; water stress; leaf area; total leaf number; stem length

\section{Introduction}

Tunisian flora is known for its diversity of medicinal plants such as henna which belongs to the family Lythraceae. Lawsonia inermis Linn (L. inermis L.) is glabrous branched shrub or small tree (2 to $6 \mathrm{~m}$ in height). It is a perennial shrub native to North Africa, Asia and Australia and it is naturalized and cultivated in the tropics of America, Egypt, India and parts of the Middle East (Kidanemariam et al., 2013; Semwal et al., 2014). The leaves are small, sub-sessile and greenish brown to dull green in color, and have either a glabrous, obtuse or acute apex with a tapering base. Flowers are small with red or rose color (Chauhan and Pillai, 2007; Kidanemariam et al., 2013). This plant is a worldwide known cosmetic agent used to stain hair, skin and nails (Vasudevan and Laddha, 2003; Semwal et al., 2014). Henna is tolerant to drought and can only grow if minimum temperatures stay above $11^{\circ} \mathrm{C}$ (Kidanemariam et al., 2013). L. inermis grows wild in deserted areas, near oases and in semi arid regions (Singh and Singh, 2001).

In the arid and semi-arid Mediterranean climates, rainfall is scarce and unreliable resulting in various abiotic stresses, generally, heat, drought and salinity (El-Beltagy and Madkour, 2012). Besides, drought is an abiotic factor that limits the development and productivity of crops. These changes can be caused by the significant reduction of photosynthetic rates, causing serious socio-economic and environmental losses (Johari-Pireivatlou et al., 2010). Furthermore, 
the use of drought-tolerant crops has been proposed for the economic exploitation of non-cultivated and marginal areas (Behera et al., 2010). Drought can significantly influence plant performance and survival and can lead to major constraints in plant functioning, including a series of morphological, physiological and metabolic changes (Claeys and Inzé, 2013; Naz and Khan, 2014). Studies also have shown that drought stress can differently affect the growth of plant organs, which may result in the alteration of the morphological features of the plants (Khan et al., 2012; Jamal et al., 2014).

The objective of this study is to characterize the effects of three different irrigation regimes on the morphological traits of henna plants, including stem length, leaf number, which are some of the traits frequently investigated to evaluate physiological responses of plants under water stress.

\section{Materials and Methods}

\subsection{Plant material and growing conditions}

Seeds of Lawsonia inermis were obtained from plants that were collected from the oasis of chenini; one of the most important oases of south-eastern of Tunisia (Latitude $33^{\circ} 53$, Longitude $10^{\circ} 12$ ). Its climate is Mediterranean dry, hot summers and mild winters. Rainfall is low and erratic with an average of $186 \mathrm{~mm}$. Evapotranspiration is estimated at 1417 mm year-1 $^{-1}$ (Kouki and Bouhaouach, 2009). L. inermis seeds were grown into $4 \mathrm{~L}$ plastic pots. Those were filled with a mixture of sand and soil (1:2); two seeds per pot were planted and the soil was irrigated with distilled water until henna germination. The maximum of germination rate was observed after 15 days. At this stage, the seedlings were thinned to one per pot and irrigated three times per week. Plants were then grown in a green-house as follows: $25 \pm 1{ }^{\circ} \mathrm{C}$ temperature, $50 \%$ day/ $75 \%$ night relative humidity and $16 \mathrm{~h}$ light/8 h dark regime. The experiment was arranged in a growth chamber with three treatments $X$ three replicates. At the age of 2 months old, 9 plants (3 plants per treatment) were irrigated to field capacity (control, T0), 50\% of the control (moderate stress, T1) and 25\% of the control (severe deficit irrigation, T2), the experiments were conducted from August and maintained until November.

\subsection{Measurements}

Leaf area (LA) was measured on the three youngest, fully expanded leaves from each pot at 15, 30, 45 and 60 days after commencement of the bioassay. LA $\left(\mathrm{cm}^{2}\right.$ plant ${ }^{-1}$ ) was measured by scanning leaves using an area meter ADC (Analytical Development Co. Ltd; AM 100). The measured parameters included the leaf appearance rate (leaf day ${ }^{-1}$ plant $^{-1}$ ) measured every two weeks, during two months, by counting the number of green leaves. Stem growth characteristics were monitored by measuring length from substrate surface to the apical meristem.

\section{Statistical analysis}

Data collection was carried out regarding three replications of the same henna cultivar for each measurement. A couple of factors (3 irrigation levels Vs 4 survey dates) have been subject of statistical analysis of the same henna cultivar behavior. Analysis of variance (ANOVA) at $\alpha=0.05$ showed significant differences between and within factor combinations. Duncan's new multiple range test (MRT) was used to compare means and to distinguish between henna responses to each irrigation regime for each survey date.

\section{Results and Discussion}

\subsection{Changes in henna leaf area development under water stress}

The leaf, being the first organ to show visible signs of drought, may provide cheap and easy traits to record for selection under water deficit. The LA of each treatment used in Fig. 1 is the average value of three replicates under the same treatment. Our results showed that, LA values were higher in control plants than the water stressed ones; LA, in general, was higher under favorable conditions (T0) than under water deficit conditions T1 and T2 (Fig. 1). Indeed, we noticed that under well watered conditions (T0) henna LA ranged from $2.45\left(\mathrm{~cm}^{2}\right.$ plant $\left.\mathrm{t}^{-1}\right)$ at $15 \mathrm{~d}$ after initiation of the irrigation to $8.88\left(\mathrm{~cm}^{2}\right.$ plant $\left.{ }^{-1}\right)$ at $60 \mathrm{~d}$. Water deficit reductions of LA were similarly observed in many species of Populus L., Watkins, etc. (Thakur and Sood, 2005), and in Eragrostis curvula (Schrad.) Nees (poaceae), Oryza sativa L. (Poaceae), Abelmoscus esculentus (L.) Moench. (Malvaceae) and Asteriscus maritimus (L.) Less. (Asteraceae) (Rucker et al., 1995).

Under mild stress T1 (50\% FC), LA decreased from 8.88 to $5.51\left(\mathrm{~cm}^{2}\right.$ plant $\left.{ }^{-1}\right)$ showing a reduction by around $37.98 \%$, as compared to the control. Thus, at severe stress (T2), the mean value of LA was $3.04\left(\mathrm{~cm}^{2}\right.$ plant $^{-1}$ ). The percentage of reduction found after the application of this severe water stress was $65.79 \%$ comparing to T0; which meant that L. inermis showed less tolerance to water shortage (25\% FC). In addition, exposure to drought stress led to a significant changes in LA that were confirmed by ANOVA test revealing that the effect of $\mathrm{T} 2$ irrigation was significant at $\mathrm{P}$ $<0.0001$. Several studies showed that water shortage causes significant reductions in LA development. In fact, the limitation of leaf growth is an adaptative mechanism to reduce transpiration (Kramer and Boyer, 


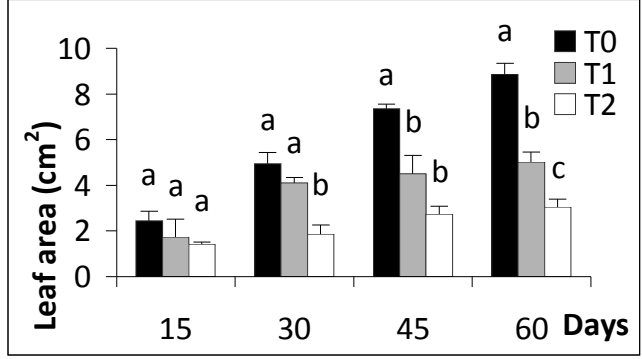

Fig. 1. Variation of leaf area (LA) in henna plants under T0 (control), T1: moderate deficit irrigation $(50 \% \mathrm{FC})$ and $\mathrm{T} 2$ : severe deficit irrigation (25\% FC) at 15, 30, 45 and 60 days, after initiation of irrigation regimes. Data represent the means \pm S.E. $(n=3)$. Means with different letters are significantly different at $P<0.05$.

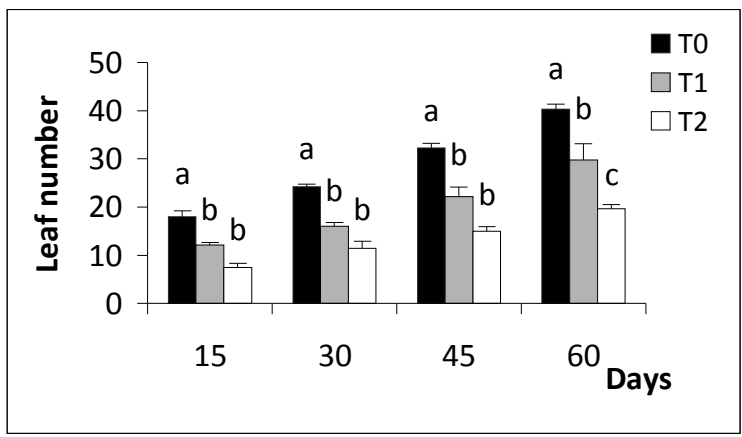

Fig. 2. Variation of total leaves number in henna plants under T0 (control), T1: moderate deficit irrigation (50\% $\mathrm{FC})$ and $\mathrm{T} 2$ : severe deficit irrigation $(25 \% \mathrm{FC})$ at $15,30,45$ and 60 days, after initiation of irrigation regimes. Data represent the means \pm S.E. $(n=3)$. Means with different letters are significantly different at $P<0.05$.

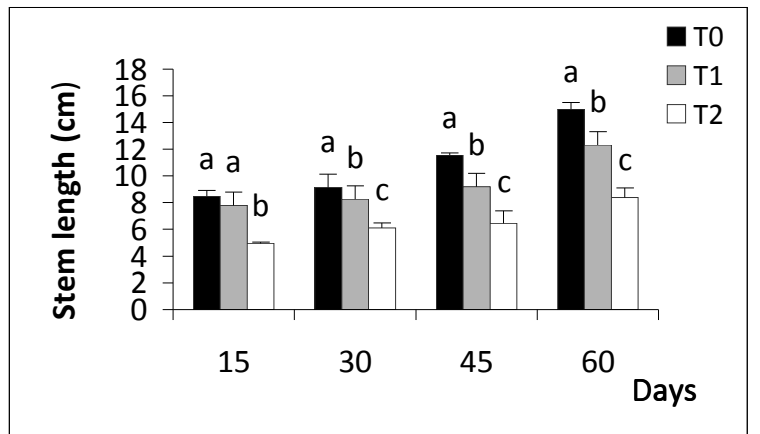

Fig. 3. Variation of stem elongation in henna plants under T0 (control), T1: moderate deficit irrigation $(50 \% \mathrm{FC})$ and T2: severe deficit irrigation $(25 \% \mathrm{FC})$ at $15,30,45$ and 60 days, after initiation of irrigation regimes. Data represent the means \pm S.E. $(n=3)$. Means with different letters are significantly different at $P<0.05$.

1995). Furthermore, the increases in soluble compounds, such as sugars and phenolic compounds, in response to drought have been described for Populus $\mathrm{x}$ canadensis Moench. (Salicaceae) (Marron et al., 2002) and may facilitate the maintenance of high turgor pressure in leaves (Van Volkenburgh and Taylor, 1996; Bouchabke et al., 2006). Cell division decreases (Granier and Tardieu, 1999), reduction of cell wall extensibility, as a result of inhibition of wall loosening or promotion of wall stiffening associated with thicker walls (Niinemets, 2001; Cosgrove, 2005); each of these phenomena was a form of adaptation to drought.

\subsection{Variation of henna leaf number under water stress}

These traits were significantly different depending on irrigation factor and drought period (Fig. 2). Water deficits (T1 and T2) reduced number of leaves per plant until 50\%, as compared to control (T0). In normal conditions, the mean number of leaves for L. inermis was ( $40 \pm 0.9$ ) over $60 \mathrm{~d}$ after initiation of the bioassay. In response to the first water stress (T1), total leaf number was ranged from 40 to 29 leaves per plant over $60 \mathrm{~d}$. Analysis of variance (ANOVA) test allowed us to point up that $\mathrm{T} 1$ effect was highly significant (P $<0.0001$ ). Moreover, Duncan test showed that after the stress was set up and between the $2^{\text {nd }}$ and the $6^{\text {th }}$ weeks (15 d to $45 \mathrm{~d}$ ), L. inermis responded similarly, under both moderate and severe deficit irrigation (Fig. 2). After $45 \mathrm{~d}$, the response of henna plants to water deficit depended on the intensity of water stress. Plants exposed to drought during the vegetative growth decreased total number leaf (Passioura et al., 1992). In Vicia faba L. (Fabaceae: Faboideae), Karamos et al. (1982) reported that water shortage and increase in the interval between irrigations, resulted in a reduction in the number of leaves per plant. Differently, Guttieri et al. (2001) reported that decrease in leaf number under water stress led to a decrease in dry matter accumulation. Lefi et al. (2004) revealed too, that the water shortage led to reduction in the occurrence rate in: Medicago sativa L. (Fabaceae: Faboideae) leaves.

\subsection{Stem-elongating changes under water stress}

The initial length of the main stems was $8.5 \mathrm{~cm}$, under control condition over $15 \mathrm{~d}$, than, the stems continued to elongate during the 8-weeks-long experiment and revealed an elongation of $15 \mathrm{~cm}$ (Fig. 3). Under moderate stress (T1), L. inermis retained stem growth and showed significantly longer stem length of $12 \mathrm{~cm}$, after two months of water stress. Plants measured at $60 \mathrm{~d}$, showed a significant decrease in stem length under severe deficit irrigation (T2); this reduction was about $44 \%$ as compared to T0. Water deficit had a large impact on growth of plant stem length; in fact, our results showed that the reduction of henna growth can be seen after the application of $\mathrm{T} 1$ and T2 irrigation regimes (Fig. 3). Thus, after 8 weeks 
of the application of severe stress T2 (25\% FC), the largest percentage of reductions in stem length were 41.38\% comparing to control. Similar results were observed in Erythrina plants (Pita and Pardes, 2001), species of the genus Populus L. (Nicholas, 1998) and also in species of the genus Albizzia L. (Patel and Golakia, 1988). In citrus, Panneerselvam et al. (2007) noted that the stem length was reduced by $25 \%$ under water stress. Ravindra (1991) also reported that the stem length was significantly affected in potato under water stress. According to Manivannan et al. (2007), bean stem length decreased under water deficit, but this decrease was not significant compared to fully irrigated bean. Sankar et al. (2008) reported that reduction in the height of bean plants was associated with the enlargement of the leaf cells and plant senescence in Abelmoschus esculentus under water stress.

\section{Conclusion}

Henna responds to drought as a moderately tolerant plant. Drought response mechanisms displayed by henna plant were partially different depending on the irrigation dose. In the moderate stress (T1) henna plants were able to tolerate water stress by adapting morphological mechanisms to counter drought damage. However, at severe deficit irrigation stress (T2), plants seem to be more sensible to drought. To conclude, henna plants may be used to overcome drought rather than salinity problems in their natural areas, however, further work is necessary to test physiological mechanisms to confronting drought in semi arid regions and to increase henna production in Tunisia.

\section{References}

Behera, S. K., P. Srivastava, R. Tripathi, J. P. Singh and P. Singh. 2010. Evaluation of plant performance of Jatropha curcas L. under different agro-practices for optimizing biomass - a case study. Biomass and Bioenergy 34: 30-41.

Bouchabke, O., F. Tardieu and T. Simonneau, 2006. Leaf growth and turgor in growing cells of maize (Zea mays L.) respond to evaporative demand in well-watered but not in water saturated soil. Plant, Cell and Environment 29: 1138-1148.

Chauhan, M. G. and A. P. Pillai, 2007. Microscopic profile of powdered drug used in Indian system of medicine I Ed., Vol 2, Gujarat Ayurved University, Jamnagar, Gujarat, p. 84-85.

Claeys, H. and D. Inzé, 2013. The agony of choice: how plants balance growth and survival under water-limiting conditions. Plant Physiology 162: 1768-1779.
Cosgrove, D. J. 2005. Growth of the cell wall. Nature Reviews. Molecular Cell Biology 6: 850-861.

El-Beltagy, A. and M. Madkour, 2012. Impact of climate change on arid lands agriculture. Agriculture and Food Security 1: 3.

Granier, C. and F. Tardieu. 1999. Water deficit and spatial pattern of leaf development. Variability in response can be simulated using a simple model of leaf development. Plant Physiology 119: 609-619.

Guttieri, M. J., J. C. Stark, K. Obrien and Souza, E. 2001. Relative sensitivity of spring wheat grain yield and quality parameters to moisture deficit. Crop Science 41: 327-335.

Jamal, A., M. N. Shahid, B. Aftab, B. Rashid, M. B. Sarwar, B. B. Mohamed, S. Hassan and Husnain, T. 2014. Water Stress Mediated Changes in Morphology and Physiology of Gossypium arboreum (Var FDH-786). Journal of Plant Sciences 2(5): 179-186.

Johari-Pireivatlou, M., N. Qasimov and H. Maralian, 2010. Effect of soil water stress on yield and proline content of four wheat lines. African Journal of Biotechnology 9: 36-40.

Karamos, A., J. Elston and H. Wadsworth. 1982. Water stress and leaf growth of field beans (Vicia faba L.) in the Field. Water potentials and laminar expension. Annals of Botany 49: 815-826.

Khan, M. A. I., M. A., Hoque, A. M. Farooque, U. Habiba and M. A. Rahim. 2012. Physio-morphological features of Chilli accessions under moisture stress conditions. Bangladesh Journal of Agricultural Research 37(2): 263-269.

Kidanemariam, T. K., T. K. Tesema, K. H. Asressu and A. D. Boru. 2013. Chemical investigation of Lawsonia inermis L. leaves from Afar region, Ethiopia. Oriental Journal of Chemistry 29: 129-134.

Kouki, K. and H. Bouhaouach. 2009. Study of traditionnal oasis Chenini Gabès in southern east of Tunisia. Tropicultura 27(2): 93-97.

Kramer, P. J. and J. S. Boyer. 1995. Water relations of plants and soils. Academic Press, San Diego, 495 pp.

Lefi, E., J. Gulias, J. Cifre, M. Ben Yones and H. Medrano. 2004. Drought effects on the dynamics of leaf production and senescence in field-grown Medicago arborea and Medicago citrina. Annals of Applied Biology 144: 196-176.

Manivannan, N., N. Puppala and S. G. Delikostadinov, 2007. Association between pod and kernel characteristics in Valencia groundnut, Arachis hypogaea L. sub sp. fastigiata var. fastigiata. Journal of Oilseeds Research 24: 170-171. 
Marron, N., D. Delay, J. M. Petit, E. Dreyer, G. Kahlem, F. M. Delmotte and F. Brignolas. 2002. Physiological traits of two Populus $\times$ euramericana clones, Luisa Avanzo and Dorskamp, during a water stress and re-watering cycle. Tree Physiology 22: 849-858.

Naz, H. and N. Khan. 2014. Role of abscisic acid and water stress on the activities of antioxidant enzymes in wheat. Current Research Journal of Biological Sciences 6(4): 168-172.

Nicholas, S. 1998. Plant resistance to environmental stress. Current Opinion in Biotechnology 9: 214-219.

Niinemets, Ü. 2001. Global-scale climatic controls of leaf dry mass per area, density, and thickness in trees and shrubs. Ecology 82: 453-469.

Panneerselvam, R., C. A. Jaleel, R. Somasundaram, R. Sridharan and M. Gomathinayagam. 2007. Carbohydrate metabolism in Dioscorea esculenta (Lour.) Burk. tubers and Curcuma longa L. rhizomes during two phases of dormancy. Colloids Surf B Biointerfaces 59: 59-66.

Passioura, J. B., M. C. Ball and J. H. Knight 1992. Mangroves may salinize the soil and in so doing limit their transpiration rate. Functional Ecology 6: 476-481.

Patel, M. S. and B. A. Golakia, 1988. Effect of water stress on yield attributes and yield of groundnut (Arachis hypogaea L.). Indian Journal of Agricultural Sciences 58(9): 701-703.

Pita, P. and J. A. Pardes, 2001. Growth, leaf morphology, water use and tissue water relation of Eucalyptus globules clones in response to water deficit. Tree Physiology 21: 599-607.

Ravindra, V. 1991. Physiological analysis of drought resistance and yield in groundnut (Arachis hypogaea L.). Tropical Agriculture, Trinidad and Tobago 67: 290-296.

Rucker, K. S., C. K. Kvien, C. C. Holbrook and J. E. Wood. 1995. Identification of peanuts genotypes with improved drought avoidance traits. Peanut Science 22: 14-18.

Sankar, B., C. A. Jaleel, P. Manivannan, A. Kishorekumar, R. Somasundaram and R. Panneerselvam. 2008. Relative efficacy of water use in five varieties of Abelmoschus esculentus (L.) Moench. under water-limited conditions. Colloids Surf $B$ Biointerfaces 62: 125-129.

Semwal, R. B, D. K. Semwal, S. Combrinck, C. Cartwright-Jones and A. Viljoen. 2014. Lawsonia inermis L. (henna): Ethnobotanical, phytochemical and pharmacological aspects. Journal of Ethnopharmacology 155(1): 80-103.

Singh, A. and D. K. Singh, 2001. Molluscicidal activity of Lawsonia inermis and its binary and tertiary combinations with other plant derived molluscicides. Indian Journal of Experimental Biology 39: 263-268.

Thakur, P. S. and R. Sood. 2005. Drought tolerance of multipurpose agroforestry tree species during first and second summer drought. Indian Journal of Plant Physiology 10(11): 32-40.

Van Volkenburgh, E. and G. Taylor. 1996. Leaf growth physiology. In R. F. Stettler, H. D. J. Bradshaw, P. E. Heilman, T. M. Hinckley, Eds, Biology of Populus and Its Implications for Management and Conservation. Ed 1, NRC Research Press, National Research Council of Canada, Ottawa, Ontario, p. 283-299.

Vasudevan, T. N. and K. S. Laddha. 2003. Herbal drug microscopy. Ed 1, Yucca publishing house, Dombivli, New Delhi, p. 68-69. 